\title{
Halofuginone Hydrobromide
}

National Cancer Institute

\section{Source}

National Cancer Institute. Halofuginone Hydrobromide. NCI Thesaurus. Code C2656.

The hydrobromide salt of halofuginone, a semisynthetic quinazolinone alkaloid anticoccidial derived from the plant Dichroa febrifuga, with antifibrotic and potential antineoplastic activities. Halofug inone specifically inhibits collagen type I gene expression and matrix metalloproteinase 2 (MMP-2) gene expression, which may result in the suppression of angiogenesis, tumor stromal cell development, and tumor cell growth. These effects appear to be due to halofuginone-mediated inhibition of the collagen type I and MMP-2 promoters. Collagen type I and MMP-2 play important roles in fibroproliferative diseases. 